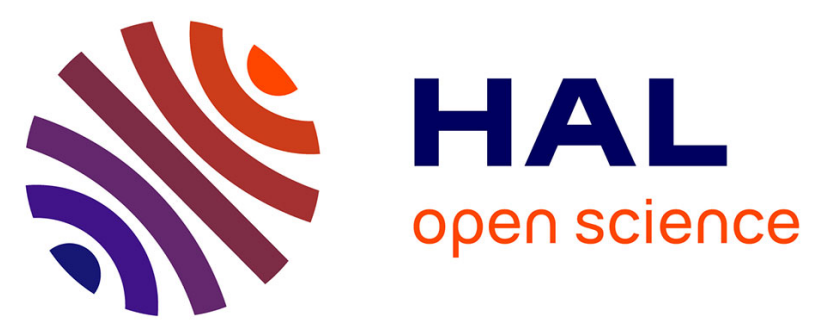

\title{
Regulation of the Ovine MT Melatonin Receptor Promoter: Interaction between Multiple Pituitary Transcription Factors at Different Phases of Development
}

Jonathan D. Johnston, Carole Schuster, Perry Barrett, David G. Hazlerigg

\section{To cite this version:}

Jonathan D. Johnston, Carole Schuster, Perry Barrett, David G. Hazlerigg. Regulation of the Ovine MT Melatonin Receptor Promoter: Interaction between Multiple Pituitary Transcription Factors at Different Phases of Development. Molecular and Cellular Endocrinology, 2007, 268 (1-2), pp.59. 10.1016/j.mce.2007.01.015 . hal-00531914

\author{
HAL Id: hal-00531914 \\ https://hal.science/hal-00531914
}

Submitted on 4 Nov 2010

HAL is a multi-disciplinary open access archive for the deposit and dissemination of scientific research documents, whether they are published or not. The documents may come from teaching and research institutions in France or abroad, or from public or private research centers.
L'archive ouverte pluridisciplinaire HAL, est destinée au dépôt et à la diffusion de documents scientifiques de niveau recherche, publiés ou non, émanant des établissements d'enseignement et de recherche français ou étrangers, des laboratoires publics ou privés. 


\section{Accepted Manuscript}

Title: Regulation of the Ovine $\mathrm{MT}_{1}$ Melatonin Receptor

Promoter: Interaction between Multiple Pituitary

Transcription Factors at Different Phases of Development

Authors: Jonathan D. Johnston, Carole Schuster, Perry Barrett, David G. Hazlerigg

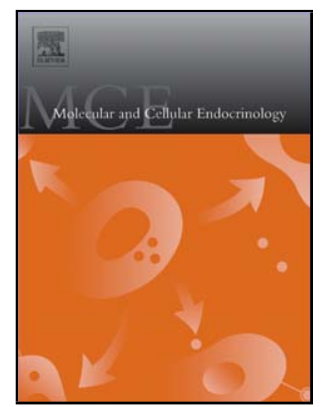

PII:

DOI:

Reference:

S0303-7207(07)00034-2

doi:10.1016/j.mce.2007.01.015

To appear in: $\quad$ Molecular and Cellular Endocrinology

Received date: $\quad 26-8-2006$

Revised date: 16-12-2006

Accepted date: $\quad$ 24-1-2007

Please cite this article as: Johnston, J.D., Schuster, C., Barrett, P., Hazlerigg, D.G., Regulation of the Ovine $\mathrm{MT}_{1}$ Melatonin Receptor Promoter: Interaction between Multiple Pituitary Transcription Factors at Different Phases of Development, Molecular and Cellular Endocrinology (2007), doi:10.1016/j.mce.2007.01.015

This is a PDF file of an unedited manuscript that has been accepted for publication. As a service to our customers we are providing this early version of the manuscript. The manuscript will undergo copyediting, typesetting, and review of the resulting proof before it is published in its final form. Please note that during the production process errors may be discovered which could affect the content, and all legal disclaimers that apply to the journal pertain. 
1 Regulation of the Ovine $\mathrm{MT}_{1}$ Melaton in Receptor Promoter: Interaction between

2 Multiple Pituitary Transcription Factors at Different Phases of Development

3

4 Jonathan D. Johnston ${ }^{\mathrm{a},{ }^{*}}$, Carole Schuster ${ }^{\mathrm{b}, \mathrm{c},{ }^{*}}$, Perry Barrett ${ }^{\mathrm{b}}$, and David G. Hazlerigg ${ }^{\mathrm{d}}$. 5

$6 \quad{ }^{\mathrm{a}}$ School of Biomedical and Molecular Sciences, University of Surrey, Guildford GU2

$7 \quad 7 \mathrm{XH}, \mathrm{UK}$

$8 \quad{ }^{\mathrm{b}}$ Molecular Neuroendocrinology Group, Rowett Research Institute, Aberdeen AB21

9 9SB, UK

$10{ }^{\mathrm{C} C}$ Current address: SERVIER MONDE, 22 rue Garnier 92578 Neuilly Sur Seine

11 Cedex, France

$12{ }^{\mathrm{d}}$ School of Biological Sciences, University of Aberdeen, Aberdeen AB24 2TZ, UK

$13 *$ *DJ and CS contributed equally to this work

14 Corresponding author: Dr Jonathan D Johnston

15

16

17

18

19

23 The sequence of the ovine $\mathrm{MT}_{1}$ gene described in this study has been submitted to the

24 Genbank database under accession number $\underline{\text { AY524665 }}$

School of Biomedical and Molecular Sciences

The University of Surrey

Guildford

Surrey GU2 7XH

UK

j.johnston@surrey.ac.uk

tel: +44 (0) 1483686470

fax: +44 (0) 1483686401 
Key words: Pitx-1; Egr-1; pars distalis; gonadotroph; pars tuberalis; E-box

\section{Abstract}

Pineal secretion of melatonin provides a neuroendocrine representation of the lightdark cycle, which is used to synchronise daily and annual rhythms of physiology and behaviour. In mammals, melaton in primarily acts through $\mathrm{MT}_{1}$ melatonin receptors that exhibit a highly restricted tissue distribution. Expression of $\mathrm{MT}_{1}$ receptors is subject to developmental and circadian control, which likely modulates the physiological actions of melatonin. To investigate the mechanisms controlling $\mathrm{MT}_{1}$ expression we cloned the proximal $1.5 \mathrm{~kb}$ region of the ovine $\mathrm{MT}_{1}$ promoter. Sequence analysis revealed putative cis-elements for transcription factors involved in pituitary development, namely Pitx-1 and Egr-1, and multiple putative Eboxes, which are involved in both circadian and developmental gene regulation. Nuclear protein from ovine pars tuberalis (PT) cells, a site of high endogenous $\mathrm{MT}_{1}$ expression, stimulated gene expression from a $\mathrm{MT}_{1}$ expression construct, indicating the presence of a functional promoter. Pitx-1 was strongly expressed in the ovine PT and stimulated $\mathrm{MT}_{1}$ promoter activity in transfection assays. Co-transfection with Egr-1 induced promoter-specific effects: Pitx-1-stimulated $\mathrm{MT}_{1}$ activity was inhibited, whereas $\beta \mathrm{LH}$ promoter activity was enhanced.

In addition to Pitx-1 the circadian clock genes Clock and Bmall were also expressed in the PT. However, despite multiple putative E-boxes in the $\mathrm{MT}_{1}$ promoter, transfected Clock and Bmall were unable to regulate either basal or Pitx-1stimulated $\mathrm{MT}_{1}$ promoter activity. 
51 promoter, suggests a general model in which melatonin receptor expression in the

52 mammalian pituitary is determined by the developmentally changing balance between

53 stimulatory and inhibitory transcription factors. Furthermore, our data suggest that

54 circadian variation in $\mathrm{MT}_{1}$ gene expression does not depend upon the direct action of

55 circadian clock genes on E-box cis-elements. 


\section{Introduction}

The nocturnal secretion of melatonin from the pineal gland provides an endocrine representation of both circadian and seasonal time (Simonneaux and Ribelayga, 2003). In mammals, melatonin acts via two major receptor subtypes, of which $\mathrm{MT}_{1}$ (previously termed $\mathrm{Mel}_{1 \mathrm{a}}$ ) is the more prevalent (Reppert et al., 1996). Throughout life, melatonin receptor populations exhibit considerable plasticity. During early stages of development, melatonin receptors are transiently expressed in multiple neural and endocrine tissues (Davis, 1997). In adult an imals, many melatonin receptor populations exhibit 24-hour variation in receptor density (Piketty and Pelletier, 1993; Gauer et al., 1994; Recio et al., 1996; Schuster et al., 2001; Poirel et al., 2002). Currently, the significance of this plasticity and the mechanisms that drive changes in melatonin receptor expression are poorly understood.

The best characterised region of foetal melatonin receptor expression is the pituitary pars distalis (PD). In rodents, melatonin binding sites are present in the pituitary after approximately 12-15 days of gestation (Rivkees and Reppert, 1991; Williams et al., 1991; Duncan and Davis, 1993) and decline over the first 2-3 weeks of neonatal life (Vanecek, 1988; Williams et al., 1991; Vanecek and Kosar, 1994). In the ovine $\mathrm{PD}$, melatonin binding is present from 31 days of gestation through to birth, although labelling becomes more diffuse with gestational age (Helliwell and Williams, 1994). Current evidence suggests that these binding sites correspond to $\mathrm{MT}_{1}$ receptors expressed in gonadotroph cells (Martin and Klein, 1976; Martin et al., 1982; Johnston et al., 2003b; 2006). The development and regulation of this cell type is dependent on many transcription factors, includ ing pituitary homeobox-1 (Pitx-1; Szeto et al., 1999) and the lineage specific factors early growth response factor-1 
81 (Egr-1; Lee et al., 1996; Topilko et al., 1998). Pitx-1 is of particular interest as it

82 stimulates promoter activity of many pituitary-specific genes (Tremblay et al., 1998)

83 and is also highly expressed in the pituitary pars tuberalis (PT) (Lanctot et al., 1999),

84 an important site of melatonin action in seasonal mammals (Hazlerigg et al., 2001;

85 Johnston, 2004).

Putative $c i s$-elements for these gonadotroph-associated transcription factors have recently been identified in the rat $\mathrm{MT}_{1}$ promoter (Johnston et al. 2003a). Pitx-1 and Egr-1 were subsequently shown to be potent regulators of $\mathrm{MT}_{1}$ promoter activity (Johnston et al., 2003b). The $\mathrm{MT}_{1}$ receptors in rat gonadotroph cells appear to be down-regulated by the onset of hypothalamic gonadotroph in-releasing hormone $(\mathrm{GnRH})$ secretion, suggesting that the establishment of a mature hypothalamic input pathway shuts down melatonin sensitivity in these cells in this species (Johnston et al., 2003b). Whether the same pathway of developmental control also applies in larger non-rodent species, in which developmental organ isation is far more advanced at the time of birth (precocial), or in other endocrine tissues showing transient melatonin rec eptor expression, remains to be established.

Despite the developmental loss of melaton in receptors in PD gonadotroph cells, MT ${ }_{1}$ mRNA remains strongly expressed in the "PT-specific" thyrotrophs of the adult PT (Klosen et al., 2002; Dard ente et al., 2003). Daily rhythms of both $\mathrm{MT}_{1}$ expression and melaton in binding sites have been reported in the PT and suprachiasmatic nuclei (SCN) of the hypothalamus (Piketty and Pelletier, 1993; Gauer et al., 1994, Recio et al., 1996; Schuster et al., 2001; Poirel et al., 2002). Furthermore, both of these tissues rhythmically expresses multiple circadian clock genes (Reppert and Weaver, 2001; Lincoln et al., 2002; Hazlerigg et al., 2004; Johnston et al., 2005; von Gall et al, 2005), whose possible role in melatonin receptor expression has not yet 
106 been investigated. These clock genes could interact directly with the $\mathrm{MT}_{1}$ promoter,

107 or modulate the activity of other factor(s), such as Pitx-1 expressed in the PT, to

108 further regulate receptor plasticity.

109 In order to further explore the mechanisms through changes in $\mathrm{MT}_{1}$ expression

110 occur we have cloned a fragment of the ovine $\mathrm{MT}_{1}$ promoter. We identified putative

111 cis-elements for a range transcription factors, including those involved in circadian

112 gene expression, and in pituitary differentiation. We then assessed the functional

113 relevance of these elements using a combination of in vitro transcription and reporter

114 assays, together with analysis of gene expression in vivo.

115

116

117

2. Materials and Methods

118

119

\subsection{Cloning and sequence analysis}

120

121 An ovine genomic library (Barrett et al., 1994) was screened with a ${ }^{32} \mathrm{P}$-labelled

122 oligonucleotide for exon 1 of the ovine $\mathrm{MT}_{1}$ receptor sequence. Hybridising plaques

123 were plaque purified with several rounds of replating and screening. One clone was

124 analysed by restriction digestion followed by Southern analysis for a fragment likely

125 to contain $\sim 2 \mathrm{~kb}$ of sequence upstream of the coding region start site. Based on the

126 known restriction digestion pattern for the ovine $\mathrm{MT}_{1}$ sequence, a NotI/SphI fragment

127 was deemed to fulfil these requirements. This fragment was cloned into the NotI/SphI

128 site of the vector pGEM-T (Promega, UK). The sequence of the cloned fragment was

129 determined in both directions using $\mathrm{ABI}$ dye terminator sequencing reagents and 
130

131 containing $111 \mathrm{bp}$ of coding sequence.

132 Restriction fragments were prepared with lengths as indicated in the

133 manuscript, and subcloned into the luciferase reporter vector pGL3-Basic (Promega

134 UK), according to the manufacturer's protocol. These fragments covered regions -

1351534 to $-26,-716$ to $-26,-440$ to -26 and -90 to -26 , relative to the translation start

136 site.

137 Putative transcription factor cis-elements were selected using MatInspector

138 software (Quandt et al., 1995; Cartharius et al., 2005).

139

140

141

142 Nuclear extracts from a primary cell culture of ovine PT cells were prepared using the

143 protocol of Andrews and Faller (1991) using up to $10^{7}$ cells. Briefly cells were

144 resuspended in $400 \mu 1$ of ice cold buffer A (10mM HEPES-KOH pH 7.9 at $4^{\circ} \mathrm{C}$,

$1451.5 \mathrm{mM} \mathrm{MgCl}_{2}, 10 \mathrm{mM} \mathrm{KCl}, 0.5 \mathrm{mM} \mathrm{DTT}, 0.2 \mathrm{mM}$ PMSF) and allowed to swell on ice

146 for $10 \mathrm{~min}$. Cells were then spun at full speed in a microfuge for $10 \mathrm{sec}$ at room temp.

147 The nuclear pellet was then resuspended in $200 \mu 1$ of buffer C (20mM HEPES-KOH

$148 \mathrm{pH} 7.9$ at $4^{\circ} \mathrm{C}, 1.5 \mathrm{mM} \mathrm{MgCl}_{2}, 420 \mathrm{mM} \mathrm{NaCl}, 25 \%$ glycerol, $0.2 \mathrm{mM}$ EDTA, $0.5 \mathrm{mM}$

149 DTT, 0.2mM PMSF). The nuclear extract was then spun at full speed in a microfuge

150 for $2 \mathrm{~min}$. The resultant supernatant was dialysed ov ernight in buffer D (24mM

151 HEPES pH 7.9 at $25^{\circ} \mathrm{C}, 24 \%$ (v/v) glycerol, $120 \mathrm{mM} \mathrm{KCl}, 0.24 \mathrm{mM}$ EDTA, $0.6 \mathrm{mM}$

152 DTT, 0.5mM PMSF. Dialysis was carried out in 0.5-3ml cass ettes (3500MW,

153 Pierlabo Scientific) according to the manufacturer's protocol. 
The $\mathrm{MT}_{1}$ promoter-luciferase constructs were linearised with SalI, facilitating

155 a run off transcript of $2 \mathrm{~kb}$. The in vitro transcription assay was carried out in a

156 volume of 100ul containing 12mM HEPES ( $\mathrm{pH} 7.9$ ), 12\% glycerol, $0.3 \mathrm{mM}$ DTT,

$157 \quad 0.12 \mathrm{mM}$ EDTA, $60 \mathrm{mM} \mathrm{KCl}, 12 \mathrm{mM} \mathrm{MgCl}_{2}, 600 \mu \mathrm{M}$ each rNTP, $10-20 \mu \mathrm{g} / \mathrm{ml}$

158 linearised DNA template. The transcription reaction was incubated at $30^{\circ} \mathrm{C}$ for $90 \mathrm{~min}$

159 at which point RQ1 DNAse (Promega UK, 2U per ug DNA) was added to the reaction

160 and incubated for a further $30-60 \mathrm{~min}$ at $37^{\circ} \mathrm{C}$. The synthesised RNA was purified

161 with the RNeasy kit (RNA clean-up proto col, Qiagen UK). The RNA was eluted in

$16230 \mu 1 \mathrm{DEPC}$ water and concentrated by overnight ethanol precipitation at $-20^{\circ} \mathrm{C}$

163 following the addition of a one tenth volume of 3M NaAc pH5. The RNA was then

164 resuspended in 5ul of DEPC treated water and prepared for electrophores is on a

165 denaturing formaldehyde $1 \%$ agaro se gel. Following electrophoresis, the RNA was

166 transferred to a nylon membrane (Dupont UK). The RNA was UV cross-linked. The

167 membrane was then probed with a ${ }^{32} \mathrm{P}$-labelled DNA fragment containing the

168 luciferase coding sequence prepared from the plasmid pGL3 basic (Promega, UK).

2.3. Transient transfections

172 Assays were performed as described previously (Johnston et al., 2003b). Briefly,

173 COS-7 cells at 50-80\% confluence were transfected with appropriate plasmid

174 combinations, using FuGene6 (Roche), according to the manufacturer's protocol.

175 Forty-eight hours after transfection, cells were washed, enzymatically detached and

176 pelleted. Cells were then resu spended in DMEM and aliquots were either assayed for

$177 \beta$-galactosidase activity or lysed in Steady-Glo reagent (Promega) prior to 
178

179

180

181

182

183 Twenty micron coronal sections were cut through the ovine PT and stored at $-80^{\circ} \mathrm{C}$.

184 Radioactive in situ hybridisation was then performed as described previously

185 (Messager et al. 1999). Hybridised sections were then exposed to autoradiographic

186 film (Kodak X-omat) for 5 days. Resultant images were digitised using an Epson

187 transmittance scanner.

188

189

190

191

192 template for Pitx-1 was cloned by PCR from a Pitx-1 expression vector supplied by

193 Dr J Drouin. All templates were ligated into pGem-T-easy (Promega, UK), according

194 to the manufacturer's instructions. The cDNA templates corresponded to bases 556-

1951009 of Genbank accession number AF000998 (Clock), 1273-1677 of Genbank

196 accession umber AF070917 (Bmal1), and 544-1140 of Genbank accession number

197 NM_011097 (Pitx-1).

198

199

The riboprobes used in this study have been previously used for analys is of gene expression (Messager et al., 1999; Lin coln et al., 2002; Johnston et al., 2003a).

The templates for Clock and Bmall probe synthesis were cloned by reverse transcriptase PCR of total RNA prepared from ovine PT tissue. The riboprobe

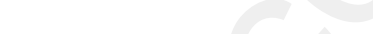

\subsection{Statistical analys is}


201 Transfection data are expressed as mean \pm SEM. Data were analysed with SigmaStat 2022.0 software (Jandel Corp.), using 1-way ANOVA with Student-Newman-Keuls post203 hoc analysis. Statistical significance was defined as $\mathrm{P}<0.05$.

204

205

206

\section{Results}

207

\subsection{Sequence analysis of the ovine $M T_{1}$ promoter}

209

210 We cloned a $1.68 \mathrm{~kb}$ region of the ovine $\mathrm{MT}_{1}$ gene, extending $1.57 \mathrm{~kb}$ upstream of the 211 putative trans lation start site. Primary sequence analys is revealed multiple putative 212 cis-elements for transcription factors essential to gonadotroph development (Table 1) 213 and also multiple E-box hexamers (CANNTG).

214 The $1.68 \mathrm{~kb}$ sequence has been deposited in Genbank under accession number 215 AY524665.

\subsection{Ability of the ovine $M T_{1}$ promoter fragment to support transcription}

219 We next determined whether the cloned $\mathrm{MT}_{1}$ sequence was capable of supporting 220 gene expression. An in vitro transcription assay was performed using full length (221 1534bp) and truncated (-716bp) MT ${ }_{1}$-luciferase constructs, in conjunction with 222 nuclear extract from the ovine PT, a key site of melatonin receptor expression in vivo 223 (Morgan et al. 1994). Luciferase mRNA transcription was strongly supported by both

$224 \mathrm{MT}_{1}$ promoter constructs, but only weakly supported by the pGL3-basic vector and 225 absent following omission of either DNA or nuclear extract from the assay (Fig. 1). 


\subsection{Promoter regulation by gonadotroph-associated transcription factors}

\section{8}

The homeobox transcription factor Pitx-1, previously shown to stimulate the rat $\mathrm{MT}_{1}$ promoter (Johnston et al., 2003b), was highly expressed in the ovine PT (Fig. 2A), a well-defined site of $\mathrm{MT}_{1}$ expression. Primary sequence an alysis revealed a putative proximal cis-element for Pitx-1 within the promoter regions of the ovine $\mathrm{MT}_{1}$ gene

(Fig. 2B), suggesting a conserved role for Pitx-1 in melatonin receptor regulation. In addition, putative cis-elements for the gonadotroph-associated factor Egr-1 was observed within the ovine $\mathrm{MT}_{1}$ sequence (Table 1).

The ability of these transcription factors to regulate $\mathrm{oMT}_{1}$ promoter activity was examined using transient transfection experiments. Basal promoter activity was strongly stimulated by co-transfection of COS-7 cells with full-length (-1534bp) $\mathrm{oMT}_{1}$ reporter construct and Pitx-1 (Fig. 2C). This stimulation persisted in a truncated (-716bp) promoter construct, but was greatly attenuated in a promoter construct (-90bp) that didn't contain the putative Pitx-1 cis-element (Fig. 2C). Low levels of Pitx-1-enhanced promoter activity have been previously reported for negative control vectors and likely represent a non-specific effect on reporter activity (Tremblay and Drouin, 1999; Johnston et al., 2003b).

In contrast to the effect of Pitx-1, basal oMT 1 promoter activity was not altered by transfection with Egr-1 (Fig. 3A). Co-transfection of Pitx-1 and Egr-1 revealed that Pitx-1-stimulated promoter activity was strongly inhibited by Egr-1 (Fig. 3A). This effect of Egr-1 was dose-dependent (Fig. 3A) and qualitatively different from its strong synergis tic in teractions with Pitx-1 at the LHß promoter (Fig. 3B) and reported previously by others (Dorn et al., 1999; Tremblay and Drouin, 1999). 
In ord er to map functional cis-elements for Egr-1, we repeated Ptx-1/Egr-1 co-

252 transfection experiments using truncated promoter constructs. Due to the requirement

253 of Pitx-1 stimulation to observe Egr-1 activity, we conducted experiments using -716

254 and -440bp fragments (Fig. 4A). For both constructs, Egr-1 potently inhibited Pitx-1-

255 stimulated promoter activity (Fig. 4B, C). These data indicate that functional binding

256 sites for both Pitx-1 and Egr-1 lie with in the proximal region of the ovine $\mathrm{MT}_{1}$

257 promoter, consistent with the in silico primary sequence analysis (Table 1).

\subsection{Promoter regulation by circadian clock gene elements}

261 Finally we examined the possible role of putative E-box elements observed within the

$262 \mathrm{oMT}_{1}$ promoter (data not shown) in the reported daily rhythms of PT melatonin

263 receptor expression (Piketty and Pelletier, 1993). The mRNA of circadian clock

264 transcription factors Clock and Bmall were both expressed in the ovine PT (Fig. 5A,

265 B). However, despite their ability to stimulate arginine vasopressin (AVP) promoter

266 activity (Fig. 5c), Clock and Bmall were unable to stimu late either basal (Fig. 5C) or

267 Pitx-1-stimulated (Fig. 5D) oMT 1 promoter activity in vitro.

\section{Discussion}

272 Studies of melatonin receptor expression suggest that multiple neuroendocrine tissues

273 are transiently sensitive to melatonin secretion in developing mammals. The function

274 of these receptor populations is poorly understood. We have studied a $1.5 \mathrm{~kb}$ fragment

275 of the ovine $\mathrm{MT}_{1}$ promoter in an attempt to understand the molecular and cellular 
276

277

278

279

280

281

282

283

284

285

286

287

288

289

290

291

292

293

294

295

296

297

298

299

300

mechanisms driving expression of this receptor. Our data show that key transcription

factors involved in pituitary gland development potently modulate $\mathrm{MT}_{1}$ promoter

activity in a promoter-specific manner. These observations support the hypothesis that transient melatonin sensitivity in developing neuroendocrine tissues is closely

related to events involved with cell differentiation. In contrast, the circadian clock

genes Clock and Bmall were not able to regulate $\mathrm{MT}_{1}$ promoter activity, suggesting

that 24-hour changes in melatonin receptor expression are not directly driven by

circadian clock genes acting via E-boxes.

There are 2 main subtypes of mammalian melatonin receptor, $\mathrm{MT}_{1}$ and

MT2. Our study has focussed on the $\mathrm{MT}_{1}$ receptor, whic h exhibits far greater

expression within the neuroendocrine system (Reppert et al., 1996).

Furthermore, although some species of hamster are believed to lack a functional

$\mathrm{MT}_{2}$ receptor, their neuroendocrine physiology remains sen sitive to effects of

melatonin, indicating that $M T_{1}$ is also the most functionally relevant subtype in

this system (Weaver et al., 1996). We have recently shown that the rat $\mathrm{MT}_{1}$

promoter contains multiple putative cis-elements for gonadotroph-associated

transcription factors (Johnston et al., 2003a), and that some of these factors potently

regulate promoter activity (Johnston et al., 2003b). In this paper, we show that

putative elements for the transcription factors Pitx-1 and Egr-1 are also located in the ovine $\mathrm{MT}_{1}$ promoter, suggesting a possible conservation of promoter regulation between species. This high level of similarity also extends to the regulation of $\mathrm{MT}_{1}$ promoter activity. Both the rat and ovine promoters are strongly stimulated by Pitx-1 in vitro which, combined with the high level of Pitx-1 expression in the PT, strengthens the body of evidence suggesting that Pitx-1 is an important regulator of pituitary melatonin receptor expression in vivo. 
Egr-1 strongly attenuates Pitx-1-stimulated activity of both rat and ovine $\mathrm{MT}_{1}$

302 promoters. This is in marked con trast to the high level of synergism between Pitx-1

303 and Egr-1 at the gonadotroph-specific LHß promoter (Tremblay and Drouin, 1999;

304 Johnston et al., 2003b). The expression of Egr-1 in gonadotroph cells is stimulated by

305 the onset of pulsatile GnRH secretion (Dorn et al., 1999; Tremblay and Drouin, 1999),

306 which occurs during the same time window as the developmental decrease in

307 melatonin receptor expression in the rat (Vanecek, 1988; Williams et al., 1991; Ebling

308 and Cronin, 2000). In sheep, the formation of the hypo thalamic-pituitary portal

309 circulation and the appearance of GnRH terminals occur by 45 and 60 days of

310 gestation, respectively (Matwijiw et al., 1989; Polkowska, 1995), lead ing to strong

311 expression of LH $\beta$ in the pituitary by day 70 of gestation (Brooks et al., 1992).

312 Although some melatonin binding sites remain in the ovine PD throughout gestation

313 until birth, these sites appear diffuse from 59 days of gestation (Helliwell and

314 Williams, 1994). We therefore predict that this change in the pattern of PD melatonin

315 binding sites is due to the developmental activation of pulsatile GnRH secretion

316 inducing Egr-1 expression in ovine gonadotroph cells. Thus the relationship between

317 GnRH secretion and $\mathrm{MT}_{1}$ expression in the developing PD may be conserved between

318 species, irrespective of the length of gestation per se.

319 Melatonin receptors are strongly expressed in the adult PT of all species thus

320 far examined, with the possible exception of humans (Morgan et al., 1994). Co-

321 localisation studies have revealed $\mathrm{MT}_{1}$ mRNA in the "PT-specific" thyrotrophs of the

322 rodent PT (Klosen et al., 2002; Dardente et al., 2003). The failure to observe co-

323 localisation between $\mathrm{MT}_{1}$ and $\mathrm{LH} \beta$ mRNAs in adult an imals is consistent with our

324 hypothesis that $\mathrm{GnRH}$ inhibits gonadotroph $\mathrm{MT}_{1}$ expression, at least in rodent species.

325 Furthermore, the continued high expression of Pitx- 1 in the PT of adult animals 
326 (Lanctot et al., 1999; Johnston et al., 2003a; this study) suggests that the retention of

$327 \mathrm{MT}_{1}$ expression in PT-specific thyrotrophs is a result of continued expression of

328 stimulatory factor(s), such as Pitx-1, coupled with an insensitivity to developmental

329 cues, such as GnRH secretion, that turn off expression in other pituitary cell types.

330 Diurnal rhythms of melaton in receptor expression have been reported in the

331 PT of different species (Piketty and Pelletier, 1993; Gauer et al., 1994; Recio et al.,

332 1996; Schuster et al., 2001). To date, evidence suggests that this phenomenon is at

333 least partially driven by melatonin-induced receptor autoregulation (Gauer et al.,

334 1994; Barrett et al., 1996; Guerrero et al., 2000; Schuster et al., 2001). However, the

335 identification of putative E-box elements in the $\mathrm{oMT}_{1}$ promoter suggested to us that

336 rhythmic melatonin receptor expression might be additionally driven by the direct

337 interaction between the ovine $\mathrm{MT}_{1}$ promoter and circadian clock genes recently

338 reported in the PT of multiple mammalian species (Lincoln et al., 2002; Hazlerigg et

339 al., 2004; Johnston et al., 2005; von Gall et al., 2005). Such a mechanism is believed

340 to drive the rhythmic expression of some "circadian output" genes, which do not form

341 a core part of the molecular circadian mechanism (Jin et al., 1999; Rip perger et al.,

342 2000).

343 In our transfection assays, the clock genes Clock and Bmall were unable to

344 modulate the activity of basal or Pitx-1-stimulated promoter activity. This result

345 therefore reinforces the requirement of an appropriate E-box hexamer and/or flanking

346 regions to generate a functional "circadian E-box" cis-element, as has been discussed

347 elsewhere (Kyriacou and Rosato, 2000; Munoz et al., 2002). Although our data

348 support the hypothesis that rhythmic melaton in receptor expression is primarily driven

349 by recep tor autoregulation (Gauer et al., 1994; Barrett et al., 1996; Guerrero et al.,

350 2000; Schuster et al., 2001), it is possible that daily $\mathrm{MT}_{1}$ regulation occurs via 
351 circadian transcription elements other than E-boxes, such as D-boxes and retinoid

352 orphan receptor elements (ROREs; Ueda et al., 2005). Indeed, we have identified

353 putative D-box elements within the $\mathrm{MT}_{1}$ promoter sequence and these are the subject

354 of ongoing work.

355 Although the putative E-box elements do not appear to be involved in

356 circadian regulation of $\mathrm{MT}_{1}$ expression, we cannot rule out functional significance of

357 these promoter regions. Indeed, basic helix-loop-helix transcription factors, which act

358 via E-boxes, are involved in both lineage commitment and tissue-specific

359 transcription in multiple tissues, including the pituitary gland (Crews, 1998; Poulin et

360 al., 2000; Lamolet et al., 2004). It is therefore possible that the developmental

361 regulation of $\mathrm{MT}_{1}$ expression in the pituitary and/or other tissues that tran siently

362 express melatonin receptors is at least partially due to the interaction between E-boxes

363 and basic helix-loop-helix proteins.

364 The data described here and in previous work (Johnston et al., 2003a; 2003b;

365 2006) provide strong evidence for the regulation of melatonin receptor expression by

366 transcription factors essential to pituitary dev elopment. The significance of the

367 transient appearance of melatonin receptors in many developing tissues (Vanecek,

368 1988; Rivkees and Reppert, 1991; Williams et al., 1991; Helliwell and Williams,

369 1994) is not understood, but it probably allows foetal tissues to synchronise to one

370 another and to the light dark cycle in response to maternal melatonin secretion (Davis,

371 1997). How this enhances the developmental process is unclear, but the

372 demonstration that circadian clocks have a direct influence on the cell cycle (Dekens

373 et al., 2003; Matsuo et al., 2003) suggests that the role of melatonin may be to

374 optimise the control of cell proliferation in rapidly developing structures. Testing this

375 idea is an important goal for future studies. 


\section{Acknowledgements}

379

380 This work was funded by the Biotechnology and Biological Sciences Research

381 Council (grants 1/S11297 and 1/S17353 to D.G.H.), by the Scottish Executive

382 Environmental \& Rural Affairs Department (C.S. and P.B.), and by French

383 foundations (Fondation pour la Recherche médicale, Fondation Simone et Cino Del

384 Duca).

385 The authors gratefully acknowledge G Lincoln and D Miller for helpful comments

386 regarding this manuscript, J Drouin (Pitx-1), J Milbrandt (Egr-1) and S Reppert

387 (Clock, Bmal-1) for donation of expression vectors, S Reppert for the AVP-luciferase

388 reporter plasmid and J Nils on for the LH $\beta$-luciferase plasmid. We also thank Mrs K

389 Brown for technical ass is tance.

390

391

392

393

394

395

396

397

398

399

400

\section{References}

Andrews, N.C., Faller, D.V., 1991. A rapid micropreparation technique for extraction of DNA-bind ing proteins from limiting numbers of mammalian cells. Nuc. Acids Res. $19,2499$.

Barrett, P., MacDonald, A., Helliwell, R., Davidson, G., Morgan, P., 1994. Cloning and expression of a new member of the melanocyte-stimulating hormone receptor family. J. Mol. Endocrinol. 12, 203-213. 
402 Barrett, P., MacLean, A., Davidson, G., Morgan, P.J., 1996. Regulation of the Mel 1a 403 melatonin receptor mRNA and protein levels in the ovine pars tuberalis: evidence for 404 a cyclic adenosine 3', 5'-monophosphate-independent Mel 1a receptor coupling and 405 an autoregu latory mechanism of expression. Mol. Endocrinol. 10, 892-902.

407 Brooks, A.N., Currie, I.S., Gibson, F., Thomas, G.B., 1992. Neuroendocrine 408 regulation of sheep foetuses. J. Reprod. Fert. 45, 69-84.

410 Cartharius, K., Frech, K., Grote, K., Klocke, B., Haltmeier, M., Klingenhoff, A., 411 Frisch, M., Bayerlein, M., Werner, T., 2005. MatInspector and beyond: promoter 412 analysis based on tran scription factor binding sites. Bio informatics 21, 2933-2942.

414 Crews, S.T., 1998. Control of cell lineage-specific development and transcription by 415 bHKH-PAS proteins. Genes Dev. 12, 607-620.

417 Dardente, H., Klosen, P., Pevet, P., Masson-Pevet, M., 2003. MT1 melatonin receptor 418 mRNA expressing cells in the pars tuberalis of the European hamster: effect of 419 photoperiod. J. Neuroendocrinol. 15 778-786.

421 Davis, F.C., 1997. Melatonin: role in development. J. Biol. Rhythms 12, 498-508. 
426 Dorn, C., Ou, Q., Svaren, J., Crawford, P.A., Sadovsky, Y., 1999. Activation of

427 luteinizing hormone beta gene by gonadotropin-releasing hormone requires the

428 synergy of early growth response-1 and steroidogenic factor-1. J. Biol. Chem. 274,

$429 \quad 13870-13876$.

430

431 Duncan, M.J., Davis, F.C., 1993. Developmental appearance and age related chan ges

432 in specific 2- $\left[{ }^{125} \mathrm{I}\right]$ iodomelatonin binding sites in the suprachiasmatic nuclei of female

433 Syrian hamsters. Dev. Brain Res. 73, 205-212.

434

435 Ebling, F.J.P., Cronin, A.S., 2000. The neurobiology of reproductive development.

436 Neuroreport 11, R23-R33.

437

438 Gauer, F., Mas son-Pevet, M., Stehle, J., Pevet, P., 1994. Daily variations in melatonin

439 receptor density of rat pars tuberalis and suprachiasmatic nuclei are distinctly

440 regulated. Brain Res. 641, 92-98.

441

442 Guerrero, H.Y., Gauer, F., Schuster, C., Pevet, P., Masson-Pevet, M., 2000. Melatonin

443 regulates the mRNA expression of the $\mathrm{mt}_{1}$ melatonin receptor in the rat pars tuberalis.

444 Neuroendocrinology 71 163-169.

445

446 Hazlerigg, D.G., Andersson, H., Johnston, J.D., Lincoln, G., 2004. Molecular

447 characterization of the long-day response in the Soay sheep, a seasonal mammal.

448 Curr. Biol. 14, 334-339.

449 
450 Hazlerigg, D.G., Morgan, P.J., Messager, S., 2001. Decoding photoperiodic time and 451 melatonin in mammals: what can we learn from the pars tuberalis? J. Biol. Rhythms $45216,326-335$.

453

454 Helliwell, R.J., Williams, L.M., 1994. The development of melatonin-binding sites in 455 the ovine fetus. J. Endocrinol. 142, 475-484.

456

457 Jin, X., Shearman, L.P., Weaver, D.R., Zylka, M.J., De Vries, G.J., Reppert, S.M., 458 1999. A molecular mechanism regulating rhythmic output from the suprachiasmatic 459 clock. Cell 96, 57-68.

460

461 Johnston, J.D., 2004. Photoperiodic regulation of prolactin secretion: changes in intra462 pituitary signalling and lacto troph heterogeneity. J. Endocrinol. 180, 351-356.

464 Johnston, J.D., Klosen, P., Barrett, P., Hazlerigg, D.G., 2006. Regulation of MT1

465 melatonin receptor expression in the foetal rat pituitary. J. Neuroendocrinol. 18, 5046656.

467

468 Johnston, J.D., Messager, S., Barrett, P., Hazlerigg, D.G., 2003a. Melatonin action in 469 the pituitary: neuroendocrine synchronizer and developmental modulator? J.

470 Neuroendocrinol. 15, 405-408.

471

472 Johnston, J.D., Messager, S., Ebling, F.J.P., Williams, L.M., Barrett, P., Hazlerigg,

473 D.G., 2003b. Gonadotrophin-releasing hormone drives melatonin receptor down- 
474 regulation in the developing pituitary gland. Proc. Natl. Acad. Sci. USA 100, 2831$475 \quad 2835$.

476

477 Johnston, J.D., Ebling, F.J., Hazlerigg, D.G., 2005. Photoperiod regulates multiple

478 gene expression in the suprachias matic nuclei and pars tuberalis of the Siberian

479 hamster (Phodopus sungorus). Eur. J. Neurosci. 21, 2967-2974.

480

481 Klosen, P., Bienvenue, C., Demarteau, O., Dardente, H., Guerrero, H., Pevet, P., 482 Masson-Pevet, M., 2002. The MT1 melatonin receptor and ROR $\beta$ receptor are co483 localised in specific TSH-immunoreactive cells in the pars tuberalis of the rat 484 pituitary. J. Histochem. Cytochem. 50, 1647-1657. 485

Kyriacou, C.P., Rosato, E., 2000. Squaring up the E-box. J. Biol. Rhythms 15, 483-

Lamolet, B., Poulin, G., Chu, K., Guillemot, F., Tsai, M.J., Drouin, J., 2004. TPit-

490 independent function $\mathrm{f}$ NeuroD1(BETA2) in pituitary corticotroph differentiation.

491 Mol. Endocrinol. 18, 995-1003.

492

Lanctot, C., Gauthier, Y., Drouin, J., 1999. Pituitary homeobox (Ptx1) is differentially

494 expressed during pituitary dev elopment. Endocrinology 140, 1416-1422.

495

496 Lee, S.L., Sadovsky, Y., Swirnoff, A.H., Polish, J.A., Goda, P., Gavrilina, G.,

497 Milbrandt, J., 1996. Luteinizing hormone deficiency and female infertility in mice

498 lacking the transcription factor NGFI-A (Egr-1). Science 273, 1219-1221. 
500 Lincoln, G.A., Messager, S., Andersson, H., Hazlerigg, D.G., 2002. Temporal

501 expression of seven clock genes in the suprachiasmatic nucleus and the pars tuberalis

502 of the sheep: evidence for an internal coincidence timer. Proc. Natl. Acad. Sci. USA $50399,13890-13895$.

504

505 Martin, J.E., Klein, D.C., 1976. Me latonin inhibition of the neonatal pituitary

506 response to luteinizing hormone-releasing factor. Science 191, 301-302.

507

508 Martin, J.E., McKeel, D.W., Sattler, C., 1982. Melatonin directly inhibits rat

509 gonadotroph cells. Endocrinology 110, 1079-1084.

510

511 Matsuo, T., Yamaguchi, S., Mitsui, S., Emi, A., Shimoda, F., Okamura, H., 2003.

512 Control mechanism of the circadian clock for timing of cell division. Science 302, $513 \quad 255-259$.

514

515 Matwijiw, I., Thliveris, J.A., Faiman, C., 1989. Hypothalamo-pituitary portal

516 development in the ovine foetus. Biol. Reprod. 40, 1127-1130.

518 Messager, S., Ross, A.W., Barrett, P., Morgan, P.J., 1999. Decoding photoperiodic 519 time through Perl and ICER gene amplitude. Proc. Natl. Acad. Sci. USA 96, 99385209943. 
522 Morgan, P.J., Barrett, P., Howell, H.E., Helliwell, R., 1994. Mela ton in receptors:

523 localization, molecular pharmacology and physiological significance. Neurochem. Int.

$52424,101-146$.

525

526 Munoz, E., Brewer, M., Baler, R., 2002. Circadian transcription: thinking outside the

527 E-box. J. Biol. Chem. 277, 36009-36017.

528

529 Piketty, V., Pelletier, J., 1993. Melatonin recep tors in the lamb pars tuberalis/median

530 eminence throughout the day. Neuroendocrinology 58, 359-365.

531

532 Polkowska, J., 1995. Development of the gonadotrophic and somatotrophic axes of

533 sheep. J. Reprod. Fert. Suppl. 49, 187-195.

534

535 Poirel, V.J., Masson-Pevet, M., Pevet, P., Gauer, F., 2002. MT1 melatonin receptor

536 mRNA expression exhibits a circadian variation in the rat suprachiasmatic nuclei.

537 Brain Res. 946, 64-71.

538

539 Poulin, G., Lebel, M., Chamberland, M., Paradis, F.W., Drouin, J., 2000. Specific

540 protein-protein interaction between basic helix-loop-helix transcription factors and

541 homeoproteins of the Pitx family. Mol. Cell. Biol. 20, 4826-4837.

542

543 Quandt, K., Frech, K., Karas, H., Wingender, E., Werner, T., 1995. MatInd and

544 MatInspector: new fast and versatile tools for detection of consensus matches in

545 nucleotide sequence data. Nuc. Acids Res. 23, 4878-4884.

546 
547 Recio, J., Pevet, P., Vivien-Roels, B., Miguez, J.M., Masson-Pevet, M., 1996. Daily

548 and photoperiodic melatonin binding changes in the suprach iasmatic nuclei,

549 paraventricular thalamic nuclei, and pars tuberalis of the female Siberian hamster

550 (Phodopus sungorus). J. Biol. Rhythms 11, 325-332.

551

552 Reppert, S.M., Weaver, D.R., 2001. Molecular analysis of mammalian circadian

553 rhythms. Ann. Rev. Physiol. 63, 647-676.

554

555 Reppert, S.M., Weaver, D.R., Godson, C., 1996. Melatonin receptors step into the

556 light: cloning and classification of subtypes. Trends Pharmacol. Sci. 17, 100-102.

557

558 Ripperger, J.A., Shearman, L.P., Reppert, S.M., Schibler, U., 2000. CLOCK, an

559 essential pacemaker component, controls expression of the circadian transcription

560 factor DBP. Genes Dev. 14, 679-689.

561

562 Rivkees, S.A., Reppert, S.M., 1991. Appearance of melatonin receptors during

563 embryonic life in Siberian hamsters (Phodopus sungorus). Brain Res. 568, 345-349.

564

565 Schuster, C., Gauer, F., Malan, A., Recio, J., Pevet, P., Masson-Pevet, M., 2001. The

566 circadian clock, light-dark cycle and melatonin are differentially involved in the

567 expression of daily and photoperiodic variations in $\mathrm{mtl}$ melatonin receptors in

568 Siberian and Syrian hamsters. Neuroendocrino logy 74, 55-68. 
570 Simonneaux, V., Ribelayga, C., 2003. Generation of the melatonin endocrine

571 message in mammals: a review of the complex regulation of melatonin synthesis by

572 norepinephrine, peptides, and other pineal transmitters. Physiol. Rev. 55, 325-395.

573

574 Szeto, D.P., Rodriguez-Esteban, C., Ryan, A.K., O’Connell, S.M., Liu, F., Kioussi,

575 C., Gleibermann, A.S., Izpisua-Belmonte, J.C., Rosenfeld, M.G., 1999. Role of the

576 bicoid-related homeodomain factor Pitx 1 in specifying hindlimb morphogenesis and 577 pituitary development. Genes Dev. 13, 484-494.

578

579 Topilko, P., Schneider-Maunoury, S., Levi, G., Trembleau, A., Gourdji, D.,

580 Driancourt, M.-A., Rao, C.V., Charnay, P., 1998. Multiple pituitary and ovarian

581 defects in Krox-24 (NGFI-A, Egr-1)-targeted mice. Mol. Endocrinol. 12, 107-122.

582

583 Tremblay, J.J., Drouin, J., 1999. Egr-1 is a downstream effector of GnRH and

584 synergizes by direct interaction with Ptx 1 and SF- 1 to enhance luteinizing hormone

585 beta gene transcription. Mol. Cell. Biol. 19, 2567-2576.

586

587 Tremblay, J.J., Lanctot, C., Drouin, J., 1998. The pan-pituitary activator of

588 transcription, Ptx1 (pituitary homeobox 1), acts in synergy with SF-1 and Pit1 and is 589 an upstream regulator of the Lim-homeodomain gene Lim3/Lhx3. Mol. Endocrinol.

$590 \quad 12,428-441$.

591

592 Ueda, H.R., Hayashi, S., Chen, W., Sano, M., Machida, M., Shigeyoshi, Y., Iino, M.,

593 Hashimoto, S., 2005. System-level identification of transcriptional circuits underlying

594 mammalian circadian clocks. Nat. Genet. 37, 187- 192. 
596 Vanecek, J., 1988. The melatonin receptors in rat ontogenesis. Neuroendocrinology

$597 \quad 48,201-203$.

598

599 Vanecek, J., Kosar, E., 1994. Ontogenesis of melatonin receptors in anterior pituitary

600 and pars tuberalis of Golden hamsters. Physiol. Res. 43, 379-382.

601

602 von Gall, C., Weaver, D.R., Moek, J., Jilg, A., Stehle, J.H., Korf, H.W., 2005.

603 Melatonin plays a crucial role in the regulation of rhythmic clock gene expression in

604 the mouse pars tuberalis. Ann. N. Y. Acad. Sci. 1040, 508-511.

605

606 Weaver, D.R., Liu, C., Reppert, S.M., 1996. Nature's knockout: the Mel1b

607 receptor is not necessary for reproductive and circadian responses to melatonin

608 in Siberian hamsters. Mol. Endocrinol. 10, 1478-1487.

609

610 Williams, L.M., Martinoli, M.G., Titchener, L.T., Pelletier, G., 1991. The on togeny of

611 central melatonin binding sites in the rat. Endocrinology 128, 2083-2090. 
612 Table 1. Putative cis-elements for gonadotroph-associated transcription factors in the $613 \mathrm{oMT}_{1}$ promoter.

614

\begin{tabular}{cccc}
\hline Factor & Position & Sequence & Orientation \\
\hline Egr-1 & -174 to -158 & CCGCACGGGGGCGCTGT & + \\
& -120 to -104 & CCCGGGCGGGGCGGCAG & + \\
& -60 to -44 & AGGCGGCGGGGCGGGAG & + \\
Pitx-1 & -338 to -322 & AACCTAAGCCCCCCTCC & - \\
\hline
\end{tabular}

615

616 For each element, core similarity $=1.0$ and matrix similarity $>0.86$. Positions are

617 expressed relative to ATG. 
618

619

620

621

\section{FIGURE LEGENDS}

Fig 1. Nuclear protein extracts from ovine pars tuberalis cells drive transcription from ovine $\mathrm{MT}_{1}$ promoter sequences. Ovine $\mathrm{PT}$ nuclear extract stimulates transcription from both -1534 and $-716 \mathrm{bp} \mathrm{MT}_{1}$ promoter constructs. Representative autoradiograph of an in vitro transcription assay (see Materials and Methods for details). Lane 1: full-length (-1534bp) $\mathrm{MT}_{1}$ construct; Lane 2: truncated (-716bp) $\mathrm{MT}_{1}$ construct; Lane 3: no DNA; Lane 4: pGL3-basic plasmid; Lane 5: no cell extract.

Fig 2. Pitx-1 stimulates ovine $\mathrm{MT}_{1}$ promoter activity. (A) Autoradiograph showing expression of Pitx-1 mRNA in the ovine PT. Scale bar $=1 \mathrm{~mm}$. (B) Schematic representation of the ovine $\mathrm{MT}_{1}$ promoter; $\mathrm{P}, \mathrm{Pitx}-1$ consensus sequence. Putative Pitx-1 cis-elements were identified using MatInspector software (Quandt et al., 1995; Cartharius et al., 2005). (C) Pitx-1 stimulates ovine $\mathrm{MT}_{1}$ promoter activity in transient transfection assays. Strong promoter activation occurs in full-length ($1534 \mathrm{bp})$ and truncated (-716bp) promoter fragments that contain the putative Pitx-1 cis-element, but is greatly reduced in a further truncated $(-90 \mathrm{bp})$ construct that lacks this site. The dose of Pitx-1 expression vector used was 250ng per well. Values are relative to the same reporter construct without co-transfection of Pitx-1. $* \mathrm{P}<0.05$ vs fold induction of the -90bp promoter construct.

Fig 3. Egr-1 inhibits Pitx-1-stimulated activity of the ovine $\mathrm{MT}_{1}$ promoter. (A) Egr-1 inhibits Pitx-1-stimulated $\mathrm{MT}_{1}$ promoter activity in a dose-dependent manner. (B) Pitx- 1 synergises with Egr-1 to stimulate the LH $\beta$ promoter. All experiments used the full-length (-1534bp) MT 1 promoter construct and a dose of 250ng of each expression 
643 vector per well, unless otherwise stated. ${ }^{*} \mathrm{P}<0.05$ vs basal promoter activity; ${ }^{\#} \mathrm{P}<0.05$

644 vs Pitx-1-stimulated promoter activity.

645

646 Fig 4. Egr-1 inhibits Pitx-1-stimulated activity of truncated ovine $\mathrm{MT}_{1}$ promoter

647 constructs. (A) Schematic representation of truncated $\mathrm{MT}_{1}$ promoter constructs. E,

648 putative Egr- 1 consensus sequence; P, Pitx-1 consensus sequence. (B-C) Egr-1

649 attenuates Pitx-1-stimulated activity of (B) -716bp and (C) $-440 \mathrm{bp} \mathrm{MT}_{1}$ constructs.

650 Experiments used 250ng of each expression vector per well. $* \mathrm{P}<0.05$ vs basal

651 promoter activity; ${ }^{\#} \mathrm{P}<0.05$ vs Pitx-1-stimulated promoter activity.

652

653 Fig 5. The circadian clock genes Clock and Bmall stimulate AVP, but not ovine

$654 \mathrm{MT}_{1}$, promoter activity. Autoradiographs show expression of (A) Clock and (B)

655 Bmall mRNA in the ovine PT. Scale bar $=1 \mathrm{~mm}$. (C) Clock and Bmall stimulate

656 basal AVP, but not $\mathrm{MT}_{1}$, promoter activity. (D) Clock and Bmall are unable to

657 stimulate Pitx-1-stimulated $\mathrm{MT}_{1}$ promoter activity. (C-D) Experiments used the full-

658 length (-1534bp) MT 1 promoter construct and 250ng of expression vector per well.

$659 * \mathrm{P}<0.05$ vs basal promoter activity.

660 
$\begin{array}{lllll}1 & 2 & 3 & 4 & 5\end{array}$

Johnston et al Fig 1 


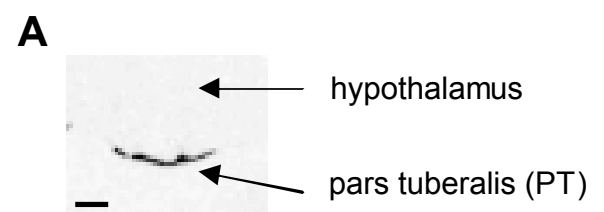

B

ovine $\longrightarrow$ P

$-1.5 k b \quad-1.0 k b \quad-0.5 k b \quad 0$

C

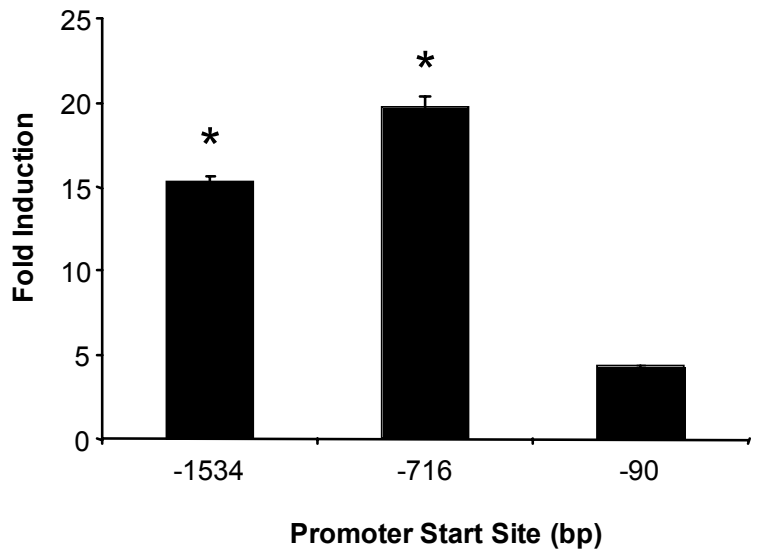

Johnston et al Fig 2 


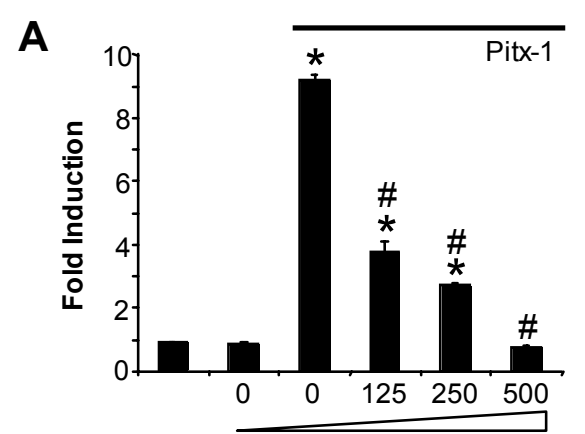

Egr-1 (ng per well)

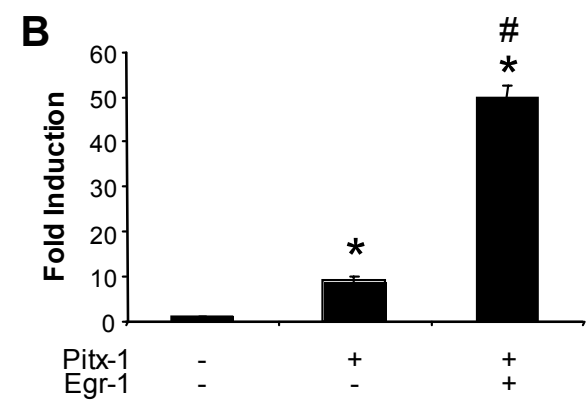

Johnston et al Fig 3 

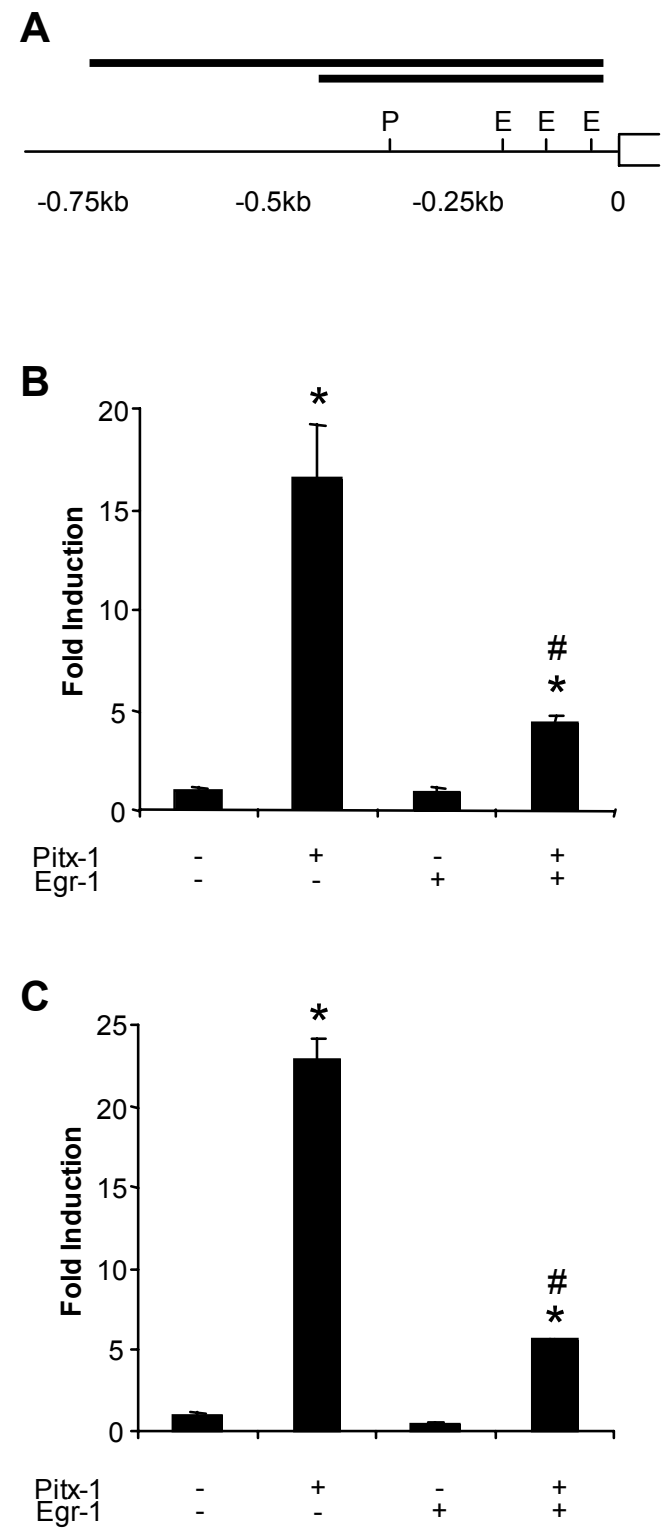

Johnston et al Fig 4 
A

B

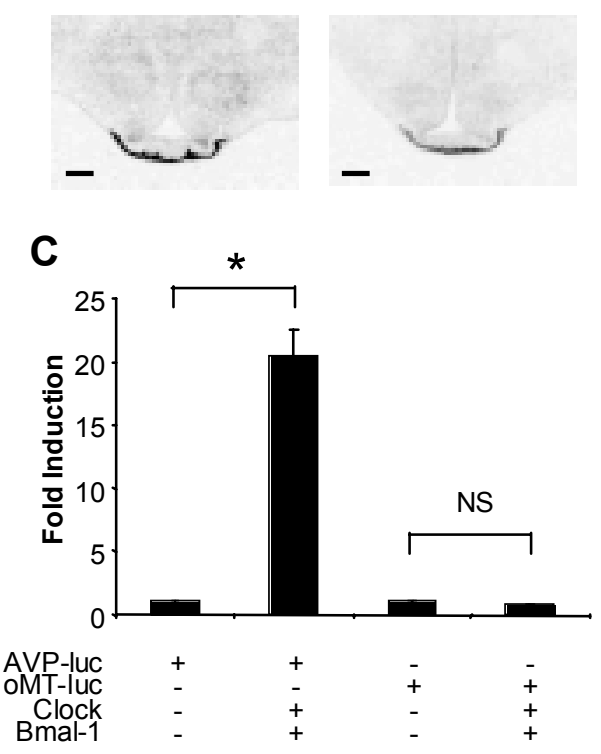

D

NS

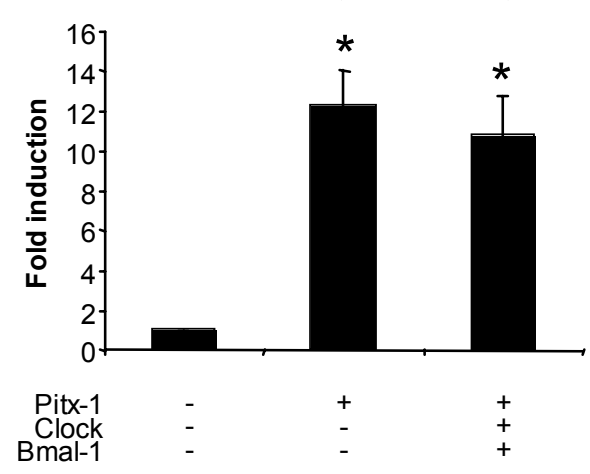

Johnston et al Fig 5 